\title{
Problems of Identifying Growth Poles in the Territory of the Ural Macroregion
}

\author{
Natalia Novikova ${ }^{1, *}$, and Alexander Leontiev ${ }^{2}$ \\ ${ }^{1}$ Ural State University of Economics, 620144 Yekaterinburg, Russia \\ ${ }^{2}$ Administration of Yekaterinburg city, 620014 Yekaterinburg, Russia
}

\begin{abstract}
The practical application of the growth pole concept is one of the possible sources of accelerating economic dynamics. The purpose of the study is to identify growth poles in the Ural macroregion. The scientific article proposes to consider the theoretical basis of the growth pole concept, as well as practical application in various forms of the growth pole concept in the territory of the Russian Federation, including in the Ural macroregion. In addition, the authors will apply theoretical and empirical methods in this study. The novelty of the authors' research lies in the hypothesis on the classification of growth poles in Russian practice, in identifying the number of growth poles in the territory of the Russian Federation and the Ural macroregion. This article will be of interest to executive authorities, the scientific community, teachers and students of higher educational institutions.
\end{abstract}

\section{Introduction}

Amid the crisis caused by the COVID-19 pandemic, large, medium and small businesses are seeking to optimize their fixed and variable costs, increase the profitability of their enterprise, and are also trying to restructure their current business models. The state, in turn, is reviewing the current economic policy, looking for new sources of economic growth.

Based on this, the search for and stimulation of endogenous factors of economic growth is of great importance for the Russian Federation. In this connection, the special significance of the scientific theory of the growth pole is currently emphasized.

\section{Materials and Methods}

The French Economist F. Perroux, one of the founders of the theory of polarization development, made the following conclusion: "growth does not appear everywhere at the same time; it manifests itself at points or poles of growth with varying intensity; it spreads through various channels and with variable final effects for the economy as a whole" [1]. In addition, on the basis of their research, the French scientist formulated the concept of

\footnotetext{
*Corresponding author: novikova@usue.ru
} 
"development pole" or "growth pole", which was understood as "a driving economic unit or a group formed by such units." "A simple or complex unit, company, industry, combination of industries is a driving force when it has side effects on other units with which it is in a relationship" [1].

Jacques Budville, a French economist, understood by the growth pole "a set of expanding industries located in an urban area and contributing to the further development of economic activity in the entire zone of its influence" [2].

At the same time, JR Lasuen, a Spanish researcher, viewed the "growth pole" as "a regional sectoral cluster of establishments associated with regional export activities, which are located in one or more geographic clusters of the region" [3]. H. R. Lasuen was of the opinion that "growth is transmitted to the sectoral periphery of the pole through direct and reverse market links (instead of links between enterprises) and to the geographic periphery through the effect of the same mechanism, adjusted for geographic factors" [3].

The American professor of economics G. Richardson believed that the "concept of the" growth pole "includes the concept of" technical polarization ", territorial agglomeration arising from decisions on the location of firms in basic industries, and the concept of geographic polarization, which implies, among other things, increasing indicators of area growth due to spatial concentration" [4].

G. Richardson also drew attention to the fact that "since growth poles in the spatial context imply, in particular, urban centers, the theory of growth poles pays great attention to the role of cities in regional development. In developed countries, the growth pole strategy often involves the concentration of infrastructure and other resources in the leading cities of lagging regions, so that these cities can act as a counterbalance to the megalopolises of prosperous areas, can connect the region through the national urban hierarchy to an interregional network of transmission of innovation, new ideas and social change. and can make intra-regional distribution of resources and population more efficient" [4].

The American Researcher M. Thomas defines the growth pole as "a group of economic activity that is concentrated in its own sphere of centripetal and centrifugal forces" [5].

J. Parr, professor emeritus at the University of Glasgow and University College London, viewed "a growth pole in geographic space as any urban center that displays specific growth characteristics (in absolute and relative terms), without any assumptions about the underlying growth or impact on its zone of influence" [6]. In addition, D. Parr argued that "an important foundation of the growth pole strategy is the assertion that the existing spatial structure is an integral part of regional economic growth, and that policy goals can only be realized if the spatial structure is modified, usually in the direction of concentration" [6].

Russian professor Pavlov K.V. notes: "the concept of growth poles is based on the idea of the leading role of the sectoral structure of the economy and, first of all, leading sectors. Those centers and areas of economic space, where enterprises of leading industries are located, become poles of attraction for production factors, since they ensure their most efficient use" [7]. According to Pavlov K.V., "the policy of creating growth poles for the purposes of regional development is aimed at careful selection of one or several potential poles in a problem region. It is here that new investments are directed instead of "pointwise" distributing them throughout the district" [7]. The scientist considers the growth poles as "territories in which industries are concentrated and propulsive industries are located", and propulsive industries are understood as "leading industries characterized by the maximum volume of production, influencing the development of the economy and possessing dynamism" [8].

Pavlov K.V. draws attention to the fact that "the main property of growth poles is to promote the development of various elements of the economy" [7]. 
As part of the study, the authors will apply theoretical and empirical methods to identify growth poles in the Ural macroregion.

\section{Results and Discussion}

The modern experience of the growth pole theory has found great practical application in the territory of the Russian Federation. According to the authors, on the territory of Russia as growth poles, based on their content and purpose, one can consider:

- clusters;

- innovative scientific and technological centers;

- special economic zones;

- territories of advanced social and economic development;

- industrial parks.

In the Russian Federation, a legislative base is being formed that defines the essence of the concept of "growth pole" (Table 1).

Table 1. The essence of the concepts of growth poles in the territory of the Russian Federation

\begin{tabular}{|c|c|}
\hline Name & Content \\
\hline Cluster & $\begin{array}{l}\text { A set of special economic zones of one type or several types, which is determined by } \\
\text { the Government of the Russian Federation and which is managed by one management } \\
\text { company. }\end{array}$ \\
\hline $\begin{array}{l}\text { Innovative } \\
\text { Science and } \\
\text { Technology } \\
\text { Center }\end{array}$ & $\begin{array}{l}\text { A set of organizations, the main purpose of which is the implementation of scientific } \\
\text { and technological activities, and other persons whose activities are aimed at ensuring } \\
\text { the functioning of such a center, operating in the territory specified by the Government } \\
\text { of the Russian Federation. }\end{array}$ \\
\hline $\begin{array}{l}\text { Special economic } \\
\text { zone }\end{array}$ & $\begin{array}{l}\text { Part of the territory of the Russian Federation, which is determined by the Government } \\
\text { of the Russian Federation and on which a special regime for carrying out } \\
\text { entrepreneurial activities is in effect, and the customs procedure of a free customs zone } \\
\text { may also be applied. }\end{array}$ \\
\hline $\begin{array}{l}\text { Territory of } \\
\text { advanced socio- } \\
\text { economic } \\
\text { development }\end{array}$ & $\begin{array}{l}\text { Part of the territory of a constituent entity of the Russian Federation, including a closed } \\
\text { administrative-territorial entity, and (or) water areas of water bodies on which, in } \\
\text { accordance with the decision of the Government of the Russian Federation, a special } \\
\text { legal regime for carrying out entrepreneurial and other activities has been established in } \\
\text { order to create favorable conditions for attracting investments, ensuring accelerated } \\
\text { socio-economic development and the creation of comfortable conditions for ensuring } \\
\text { the life of the population. }\end{array}$ \\
\hline Industrial park & $\begin{array}{l}\text { A set of industrial infrastructure facilities intended for the creation of industrial } \\
\text { production or the modernization of industrial production and managed by a } \\
\text { management company - a commercial or non-commercial organization created in } \\
\text { accordance with the legislation of the Russian Federation. }\end{array}$ \\
\hline
\end{tabular}

As part of the regulation of the polarization development of the territories of the Russian Federation, the Spatial Development Strategy until 2025 was adopted, approved by the Decree of the Government of the Russian Federation No. 207-r dated 13.02.2019. For the management of polarization development, such a territory as a macroregion is identified, which means a part of the territory of the Russian Federation, which includes the territories of two or more constituent entities of the Russian Federation, the socio-economic conditions within which require the allocation of separate areas, priorities, goals and objectives of socio-economic development when developing strategic planning documents (Federal Law of June 28, 2014 No. 172-FZ "On strategic planning in the Russian Federation").

At the moment, in accordance with the official websites of the Ministry of Economic Development of the Russian Federation, the Ministry of Science and Higher Education of the Russian Federation, "Map of Russian Clusters", "Union of Innovative and 
Technological Centers of Russia", "Industrial Parks and Technoparks of Russia", more than 500 growth poles have been formed on the territory of the Russian Federation.

In this study, and in accordance with the existing economic zoning, the Ural macroregion is outlined by the boundaries of seven constituent entities of the Russian Federation: Sverdlovsk, Chelyabinsk, Kurgan, Orenburg regions, Perm Krai, the Republics of Bashkortostan and Udmurtia.

The growth poles identified by us on the territory of the Ural macroregion are presented in table. 2

Table 2. Poles of growth in the territory of the Ural macroregion

\begin{tabular}{|c|c|c|}
\hline $\begin{array}{c}\text { Region } \\
\text { name }\end{array}$ & $\begin{array}{l}\text { Number of } \\
\text { functioning } \\
\text { growth poles }\end{array}$ & Note \\
\hline $\begin{array}{l}\text { Sverdlovs } \\
\text { k region }\end{array}$ & 14 & $\begin{array}{l}\text { Functioning growth poles: } \\
\text { - innovative scientific and technological centers ("Technopark 1993", } \\
\text { "Averon", "Avicenna", "Priborostroenie", "SSU", "Technomet", "Ural } \\
\text { Forest Technopark"); } \\
\text { - territories of advanced social and economic development (Novouralsk, } \\
\text { Lesnoy, Krasnoturyinsk); } \\
\text { - industrial parks ("Berezovsky", "PRO-BUSINESS-PARK", "Univers", } \\
\text { "Chemical park" Tagil "). } \\
\text { The following growth poles are under construction: } \\
\text { - cluster ("Titanium cluster of the Sverdlovsk region"); } \\
\text { - innovative scientific and technological centers ("Academic", } \\
\text { "IntelNedra", "Novouralsky", "Sinarsky", "University", "Kontur-park" } \\
\text { - a special economic zone ("Titanium Valley"); } \\
\text { - industrial parks ("Bogoslovsky", "Vostochny", "EKAD: Yuzhny", } \\
\text { "Yekaterinburg", "Isetsky", "Lesnoy" (TOP), "Magnitka", "Muranitny", } \\
\text { "Novosverdlovsky", "SEZ PPT Titanium Valley "," Sinarsky "," Ural ",, } \\
\text { Uralmash "," Uralsky "," GranPark "," PNK Park Berezovsky "," PNK } \\
\text { Park Koltsovo "," PNK Park Kosulino "," UL-park "). } \\
\text { At the stage of approval, including design, the creation of growth poles } \\
\text { (industrial parks): "A Plus Park Yekaterinburg", "Zarechny", } \\
\text { "Novouralsky", "DEGA-Yekaterinburg". }\end{array}$ \\
\hline $\begin{array}{l}\text { Republic } \\
\text { of } \\
\text { Bashkorto } \\
\text { stan }\end{array}$ & 12 & $\begin{array}{l}\text { Functioning growth poles: } \\
\text { - cluster (Petrochemical territorial cluster of the Republic of } \\
\text { Bashkortostan); } \\
\text { - innovative scientific and technological centers (Technopark of Aviation } \\
\text { Technologies, Inmash, Toltek SF BashSU); } \\
\text { - territories of advanced development (Belebey, Beloretsk, Kumertau, } \\
\text { Neftekamsk); } \\
\text { - industrial parks ("Building materials of Bashkortostan", "Sigma", } \\
\text { "PromCenter" LLC, "Center of agrotechnologies"). } \\
\text { The following growth poles are under construction: } \\
\text { - innovative scientific and technological centers ("Business incubator } \\
\text { Ufa", "IQ-park"); } \\
\text { - industrial parks ("Zubovo", "KhimTerra", "Sichuan-Sibay", "S11"). } \\
\text { At the stage of approval, including design, the creation of growth poles } \\
\text { (industrial parks): Salavat, Ufimsky, Veles, Nizhegorodsky, Sterlitamak, } \\
\text { Belebey, Beloretsk, Blagoveshchensky, Vorotynovsky "," GlavBashStroy } \\
\text { "," Kumertau "," Neftekamsky ". }\end{array}$ \\
\hline
\end{tabular}


Table 2. Continued

\begin{tabular}{|c|c|c|}
\hline $\begin{array}{l}\text { Chelyabin } \\
\text { sk region }\end{array}$ & 11 & $\begin{array}{l}\text { Functioning growth poles: } \\
\text { - innovative scientific and technological centers ("Technics", "IT Park", } \\
\text { "Android technology"); } \\
\text { - territories of advanced development (Bakal, Verkhniy Ufaley, Miass, } \\
\text { Ozersk, Snezhinsk); } \\
\text { - industrial parks (Stankomash, Baltika-Chelyabinsk, Sodruzhestvo). } \\
\text { The following growth poles are under construction: } \\
\text { - cluster (Cluster of lifting (crane) equipment); } \\
\text { - Innovative Science and Technology Center (TechnoPark Miass); } \\
\text { - industrial parks (Traktorozavodskaya (Technics), Rudnichny, Uvelsky, } \\
\text { Malaya Sosnovka, Novogorny, Bulat, Agroprom, DEGA-Chelyabinsk, } \\
\text { NPP, Zlatoustovskaya arms factory "," Priaysky "," Gogino "). } \\
\text { The creation of the following growth poles is in the stage of approval: } \\
\text { - an innovative scientific and technological center (Ufaleinickel); } \\
\text { - industrial parks (MMK-Metiz, Chapaevsk, Verkhny Ufaley). }\end{array}$ \\
\hline $\begin{array}{l}\text { Udmurt } \\
\text { republic }\end{array}$ & 10 & $\begin{array}{l}\text { Functioning growth poles: } \\
\text { - cluster (Udmurt machine-building cluster); } \\
\text { - innovative scientific and technological centers ("STM", "Meteor", } \\
\text { "IzhRobo", "Udmurtia", "Technovek"); } \\
\text { - territories of advanced development (Glazov, Sarapul); } \\
\text { - industrial parks ("Development", "Izhevsk plant"). } \\
\text { The following growth poles are under construction: } \\
\text { - special economic zones (PSEDA "Glazov", PSEDA "Sarapul"); } \\
\text { - industrial parks (Metallurgichesky, Agroindustrial Park of the Udmurt } \\
\text { Republic, Deryabin, Meteor, Industrialny, UHO-Kambarka, } 136 \text { TsBPR, } \\
\text { BAIKAL, STM, Sarapul Electric Generator Plant "). }\end{array}$ \\
\hline $\begin{array}{l}\text { Perm } \\
\text { region }\end{array}$ & 9 & $\begin{array}{l}\text { Functioning growth poles: } \\
\text { - clusters (innovative territorial cluster "Technopolis" New Star ", } \\
\text { innovative territorial cluster of fiber-optic technologies" Photonics "); } \\
\text { - innovative scientific and technological centers ("Morion Digital", } \\
\text { "Perm"); } \\
\text { - territories of advanced development (Nytva, Chusovoy); } \\
\text { - industrial parks ("Morion", "Krasnokamsky", "Soda-Chlorat"). } \\
\text { The following growth poles are under construction: } \\
\text { - cluster (cluster of information technologies); } \\
\text { - innovative scientific and technological centers ("Promsvyaz", } \\
\text { "Quantorium"); } \\
\text { - industrial parks ("Mechanical Plant", "Ustinovo", "Kvartal 121", } \\
\text { "Kultaevo", "Lyamino", "Motovilikha"). } \\
\text { At the stage of approval, including design, the creation of growth poles } \\
\text { (industrial parks): "Osenets", "Parma", "A Plus Park Perm" (RED). }\end{array}$ \\
\hline $\begin{array}{l}\text { Kurgan } \\
\text { region }\end{array}$ & 3 & $\begin{array}{l}\text { Functioning growth poles (priority development areas): } \\
\text { - Vargash; } \\
\text { - Dalmatovo; } \\
\text { - Kataysk. } \\
\text { The following growth poles are under construction: } \\
\text { - cluster (Kurgan territorial and industrial complex "New technologies of } \\
\text { valve construction"); } \\
\text { - an innovative science and technology center (Kurgan Regional } \\
\text { Technopark); } \\
\text { - industrial parks ("Vargashinsky", "Dalmatovo", "Ikar", "Kataysk", } \\
\text { "Kurgan", "Kurgan energomash", "Shadrinsky"). }\end{array}$ \\
\hline $\begin{array}{l}\text { Orenburg } \\
\text { region }\end{array}$ & 2 & $\begin{array}{l}\text { Functioning growth poles (priority development areas): } \\
\text { - Novotroitsk; } \\
\text { - Clear. } \\
\text { The creation of the following industrial parks (growth poles) is in the stage } \\
\text { of approval: "Orenburg downy shawl", "Mayak", "Oresta zavody", "South } \\
\text { Ural". }\end{array}$ \\
\hline
\end{tabular}

It should be noted that in addition to the currently operating growth poles in the amount of 61 units, currently more than 50 are at the stage of creation and coordination. We believe 
that they will have a polarizing effect on the economic development of not only the Ural macroregion, but also for the entire economy of the Russian Federation as a whole.

\section{Conclusion}

The concept of "growth pole" has received various practical applications in the territory of the Russian Federation, including in the Ural macro-region. In this connection, several types of growth poles were distinguished, depending on its content and purpose, but at the same time, such a variation of growth poles has spread mainly in connection with state legislative initiatives.

It should be noted that, from a historical point of view, the Urals macroregion was a growth engine for overcoming the most critical moments in the country's economy. The presence of more than 50 growth poles on the territory of the Ural macroregion, as well as their further launch will give a powerful effect to accelerate the country's economic dynamics.

\section{References}

1. F. Perroux, Paris: Presses Universitaires de France, 598 (1961)

2. J. Boudeville, Edinburg: Edinburgh U.P., 192 (1966)

3. J. R. Lasuén, Urban Studies, 10, 163 (1973)

4. H.W. Richardson, The Macmillan Press LTD, 264 (1973)

5. M. D. Thomas, Free Press, 50 (1972)

6. J. B. Parr Urban Studies, 1195 (1999)

7. K.V. Pavlov, Regional Economics: Theory and Practice, 9, 19 (2006)

8. K.V. Pavlov, Economic Bulletin of the University, Collection of scientific works of scientists and graduate students, 27-1, 129 (2015) 